\title{
Compatibility of the Relationship of Early Recollections and Life Style with Parent Schemas Obtained Through Adlerian Interviews
}

\author{
Azize Nilgün Canel ${ }^{1}$ \\ Marmara University
}

\begin{abstract}
In this study, the Adlerian Interview Form has been used as a semi-structured, in-depth interview method to identify the experiences of six participants regarding Adler's concepts of early recollections and life style. Subsequent to transcribing the obtained information, recollections to be included in the analysis were subjected to the criterion sampling method, and three recollections that met the autobiographical memory qualifications were selected. The selected recollections were investigated through narrative analysis as a qualitative research technique. Structured analysis of the narration in the analysis was carried out using Labov's narrative technique, while the method of thematic analysis was used on the themes. Parent schemas as perceived by the participants were identified with the Young Parenting Inventory (YPI), and similarities between the perceived schemas and their early recollections and life styles were determined within the context of the main themes established during the analyses. Analyses revealed that their early recollections were compatible with their life styles, and the parenting roles expressed in their recollection narratives were similar to the schemas identified in the Young Parenting Inventory.
\end{abstract}

\section{Keywords}

Adler • Early recollections $\bullet$ Life style $\bullet$ Parent schema $\bullet$ Autobiographical memory $\bullet$ Narrative analysis $\bullet$ Thematic analysis

1 Correspondence to: Azize Nilgün Canel (PhD), Department of Guidance and Psychological Counseling, Atatürk Faculty of Education, Marmara University, Istanbul Turkey. Email: nilgun.canel@marmara.edu.tr 
Several psychology theories have underlined the impact of childhood experiences on the rest of one's life, indicating that these early recollections and experiences have a lasting effect on the years that follow. The impact of early life events on an individual during subsequent years, even its relationship to potential psychological problems, continues to be the subject of much research. In particular, relationships established in one's immediate environment and related early recollections can influence in many aspects one's tendency towards depression, trust in life, tendency to create close relationships with others, anger, and so on (Matos, Gouveia, \& Duarte, 2015; Richter, Gilbert, \& McEwan, 2009). In recent years, research particularly in neuroscience has revealed that qualifying interactions created with caregivers in early development have a significant impact on the neurological development of the brain (Panksepp, 1998). The research shows that there is a positive relationship between recalling parental behaviors and recollecting positive emotional memories; in fact, positive emotional recollections are predictors in psychopathology (Richter et al., 2009). Similarly, memories of being neglected, rejected, and embarrassed, or experiences of being abused and criticized in early childhood impair brain development and lead to reactions of stress by triggering anxiety and fear in an individual (Eisenberger, 2011; Gilbert, Cheung, Grandfield, Campey, \& Irons, 2003; Perry, 2002).

As one of the theoreticians who emphasized the importance of early childhood experiences, as well as establishing a system to handle early childhood memories, Adler believed that one's perceptions of early childhood experiences also have an important impact on the rest of one's life (Jones-Smith, 2014). Instead of the individual's experiences and others' behaviors in recollected events, focusing instead on the individual's perceptions regarding these experiences provides many more clues. For example, while an individual might perceive his parents as negligent but is able to overcome this situation, another individual might recollect his parents' kindness but still have a feeling of not belonging (Gilbert et al., 2003). According to Adler, everyone develops a life plan by 5 or 6 years of age, and this plan (called life style) guides one's entire life, including the perceptions of the world and one's actions (Jones-Smith, 2014).

Having integrated content, this life style involves information about how to deal with the self, handle problems, and carry out interpersonal relations (Bienenfeld, 2005). Life style is a major key to behavior. It contains one's goals, self-opinions, world-opinions, and the habitual behaviors used to achieve desired outcomes. An individual's view of self, others, and the universe forms a personal filter for all future experiences (Jones-Smith, 2014).

In general, the experiences involved in early recollections seem to be associated with the tendencies that are dominant in one's current life. Early recollections present one with a life story that is continuously recurring and leads to stimulating or relieving 
effects at times; it sometimes inspires and helps one focus on life goals and face the future through a currently tried structure under the light of the past (Barrett, 1980; Kaplan, 1985; Maree, 2013). Cochran (cited in Maree, 2013, p. 5) stated that one or more of an individual's early recollections present the first prototypes of one's life scenario. For instance, if the first narrative contains danger or punishment, this can lead to lifetime of hostile feelings in the individual. Early recollection regarding the birth of a new sibling can give one a feeling of losing the throne (Jones-Smith, 2014). Adlerian therapy regards clients' early recollections as their primary instrument of assessment. Basically, clients are asked to think back as far as possible and talk about their early recollections, their age at the time, what kind of an event it was, and their feelings regarding this event. Adler believed that one's earliest recollections of choice are compatible with one's fundamental self-beliefs and world-beliefs. Knowing clients' first recollections helps them to easily transfer false beliefs of the self and world, social interests, and future actions to the counseling environment (Jones-Smith, 2014).

Therefore, Adler predicted a relationship between individuals' early recollections and their life style. Primary recollections present a preview of the big story (life style) that is still going on (Maree, 2013). One can make faulty interpretations of events, which may lead to mistaken beliefs or cognitions within one's private logic. Therefore, early recollections are very important instruments by themselves when determining the life style of a client during therapy (Jones-Smith, 2014; Murdock, 2012). According to Adler (cited in Barrett, 1980), early recollections are never coincidental; in fact, these recollections represent the story of one's life. Through these stories, the self may feel protected, relieved, focused on goals, or stimulated. These stories provide information about the future through already tried experiences. During counseling, the therapist first assesses the life style of the client, then collects and interprets information about one's early recollections. Clients' early recollections and life style experiences can easily be revealed by asking the questions that Adlerian psychotherapy considers important. Questions regarding the birth order of the clients, parenting style of the family, their relations with their family and siblings, and such are asked about together with their early recollections, thus making it possible to collect clues about their life style. People tend to recollect memories that are selectively compatible with their life styles (Kaplan, 1985; Mosak \& Maniacci, 2012).

The importance Adler placed on life events still occupies a significant position in current psychotherapy. For instance, Adler believed that life style is based on one's interpretation of events, rather than the events themselves (Jones-Smith, 2014). The main focus of current post-modern therapies is on the meanings and interpretations inferred by clients regarding their life events. According to these therapies, people live their lives with the narratives they tell themselves or that other people tell about them. What creates reality is the meaning ascribed to the experiences as well as the 
experiences themselves. Meaning is ascribed to one's experiences and realities, as opposed to truths or rationalism; these meanings can turn into life stories (Polkinghorne, 2000; Prochaska \& Norcross, 2010; Sommers-Flanagan \& Sommers-Flanagan, 2004).

In Schema therapy, which was established by Young, Klosko, and Weishaar (2003), early maladaptive schemas consist of recollections, feelings, cognitions, and physical senses that form extensive and lifelong prevailing cognitive patterns. A schema is a mental structure used to interpret and adapt the self to what is happening; it carries out life tasks and affects one's ways of thinking, feeling, behaving, and establishing relationships. All intellectual structures that the self uses to adapt to one's environment throughout life are developed based on these schemas. A schema is an organized structure of information starting from childhood and repeating constantly throughout life; when universal emotional requirements during childhood are met, they affect one's psychological health and compatibility (Arntz \& Genderen, 2013; Young, 2003; Young \& Klosko, 2013). Schema has roots in early childhood experiences. The development of schemas starts with something that one's family, authority figures, other children, or someone important did (Young \& Klosko, 2013). When maladaptive schemas come into play, it is generally a repeated scene similar to one experienced with the parents during childhood (Young, 2003). Since schemas develop especially between the periods of childhood and adolescence, fundamental childhood images and recollections identifying the needs that are more or less met during this period play an important role in the case conceptualization of schema therapy, as with Adlerian therapy (Ulutürk, 2014). Because individuals see the world through schemas, due to maladaptive schemas, they may not be able to enjoy life or feel delight with achievements in spite of social status, an ideal marriage, appreciation of immediate environment, or professional success (Bricker \& Young, 2012; Young \& Klosko, 2013). Although some studies have researched the relationships between parent schemas and psychological health in Turkey (Soygüt \& Çakır, 2009; Ünal, 2012), no study has investigated the relationship of parent schemas with early recollections and adopted life style.

In the relevant literature, to use the content provided by early recollection experiences in terms of a client's contextual assessment is highly valued in psychological counseling. Sharing these experiences in a counseling setting is regarded as a highly valuable technique in terms of empathetic interaction (Clark, 2001; Kaplan, 1985). While the early recollections and life-style experiences, as well as the relationship between these, have been included to date in various studies in the relevant literature, no study in the Turkish literature has yet to discuss this. The success of a counseling relationship is experienced as long as it cures the suffering of the client and turns it into hope. When unexpected or undesirable events occur in clients' lives, this experience can easily turn into their story and be the source of suffering (Maree, 2013). Exploring 
this relationship through examples specific to Turkish culture is expected to have an explanatory and guiding contribution to the psychological counseling relationship in particular. Moreover, discussing early recollections and life style experiences in terms of perceived parenting attitudes may provide a content that enriches the literature. Within this context, purposes of the study can be summarized as follows: (a) Are there similarities or compatibility between one's early recollections and life styles? (b) Are there similarities between the themes of one's early recollections and life styles and one's perceived parenting styles?

\section{Method}

This study has been conducted from a qualitative perspective, and qualitative research techniques were used during the analysis of collected data. In the study, participants presented information through a semi-structured, in-depth interview technique, and narrative analysis was used for their assessment. The main reason for choosing narrative analysis is the fact that its primary goal is to explain the underlying message of the text and the way it was presented. Narrative analysis is chosen particularly when the question of the study is focused on individuals, as is the case with this study (Tanyaş, 2014). The most distinctive aspect of narrative analysis is that it analyzes the content of the narrative and the strategic purposes or actions realized by this content (Feldman, Sköldberg, Brown, \& Horner, 2004; Riessman, 2008). Narrative analyses can be carried out in accordance with various stylistic reviews, semiotic analyses, discourse analyses, or any combination thereof. However, narrative analysis essentially focuses on two aspects: (a) Structural analysis includes discourse of the text (i.e., how the story is narrated) and (b) thematic analysis includes the content of the story (i.e., what happens to whom; Riessman, 2008). In this study, structural analysis of the narrative has been carried out using Labov's narrative method (Labov \& Waletsky, 1967). The thematic analysis method was also used with the purpose of capturing the main theme of the narrated story.

\section{Study Group}

The study was conducted on a total of six voluntary participants who consented to volunteer in the study to have an in-depth interview. These interviews were made with the participants during November and December of 2014 through face-to-face interviews in appropriate settings by taking written records of their narratives. Criterion sampling method was used when determining which data would be included in the analysis. Criterion sampling is a method in which the relevant situation or situations are addressed in the study in accordance with predetermined criterion or criteria. To this end, the criterion to be met for the collected data was taken as autobiographical memory qualifications, and the narratives were reviewed according to this criterion (relevant 
criteria are described in the data analysis section). After ruling out the recollections that did not meet these criteria, five participants were seen to remain who had met all the criteria properly; three recollection narratives from these five participants were included in the study report. Among these three narratives, one focused on the father while another one focused on the mother; these had negative content themes. The last one was defined as a positively themed recollection with the intent of ensuring diversity and addressing the subject from a wider perspective. The procedure regarding the autobiographical memory qualifications is described below in detail.

\section{Data Collection Tools}

Two different data collection tools were used in this study.

Adlerian Interview Form. A semi-structured in-depth interview method was used to assess life style. In the semi-structured interview, topics to be addressed were predetermined, and the interview form included a list of these topics. Semi-structured interviews are flexible and standardized to an extent, and they help to obtain indepth information about a certain subject by eliminating the restrictions of tests and questionnaires based on writing and filling in blanks (Yıldırım \& Şimşek, 2003). The Adlerian interview questions, structured by Alfred Adler, were used for this purpose in this study. The question form also includes early recollection experiences.

The Adlerian Interview Question Form, consisting of questions proposed by Adler, is included in Appendix 1 (Jones-Smith, 2014). The question form was translated into Turkish and then back to English; then it was discussed in terms of linguistic consistency with faculty members specialized in the field. Interviews with the participants took from one to one and a half hours. Participants were particularly encouraged to give a detailed narrative for the tenth question, which asked for early childhood recollections. Data transcription was carried out by the students of Psychological Counseling and Guidance who were taking the Psychotherapies course.

Young Parenting Inventory (YPI). Participants also completed the Young Parenting Inventory (YPI; Soygüt, Çakır, \& Karaosmanoğlu, 2008). This inventory was developed by Young in 1994. It consists of 72 items and involves questioning a variety of parental behaviors which are thought to constitute the basis for early maladaptive schemas. Validity and reliability study of the inventory in Turkey was carried out by Soygüt et al. (2008). The inventory requires the assessment of questions about both the mother and the father. Researchers reached a 10 -factor common structure in terms of both the maternal and paternal forms. The resulting dimensions on parenting were: normative, belittling/criticizing, emotionally depriving, exploitative/abusive, overprotective/anxious, conditional/achievement- 
focused, over-permissive/boundless, pessimistic/worried, punitive, and restricted/ emotionally inhibited. It was concluded to be a valid and reliable assessment tool of acceptable level with regard to its applicability in clinical practice and research activities in Turkey. The internal consistency coefficients ranged between .86 and .88 based on these analyses. Participants were instructed to rate the behaviors as best they could, separately describing their mothers and fathers during their childhood, using a 6-point Likert-type scale ranging from 1 (totally wrong) to 6 (totally fits).

\section{Data Analysis}

Procedure steps used in data analysis are given below in order:

First step: Data collection through semi-structured interview. The 18-question Adlerian Interview Form was applied to six participants in accordance with the purpose of the study. After it was applied, the interviews were transcribed.

\section{Second step: Choosing recollections that meet autobiographical memory} qualifications. The autobiographical memory containing autobiographical recollections consisted of personal semantic information, such as where the person lives, or self-information, as well as personal memories like early recollections of life or certain events from one's first day at school. In a sense, these can also be called the person's life-events memories. In general, autobiographical memory is where feelings, goals, and personal meanings cross each other (Sarp \& Tosun, 2011). With the aim of testing the appropriateness of the collected recollections in terms of narrative analysis, in order to improve the reliability of the study, each transcription was checked to see whether it had met the autobiographical memory qualifications or not. The recollections that were evaluated in the study were selected by two different groups of questions. The first group consisted of questions in the dimension of flash memories, included in the interview form developed by Er and Uçar (2004) in accordance with the most emphasized aspects of autobiographical memory in the literature. Additionally, questions from the inventory that had been developed by Talarico, Labar, and Rubin (2004) to identify the predictive power of the positive and negative value of a recollection, as well as its emotional intensity on the phenomenological aspects of the autobiographical memory, were also used. Narratives that could give responses to the questions below were selected for semantic analysis. The criteria to be met were chosen as the participants' age in their earliest recollections; whether they recalled the time of the event or what they were wearing was not taken as a criterion. After this step, three recollections meeting all of the following criteria were found appropriate to create the basic recollection pool of the study and be subjected to semantic analysis. The criteria which were evaluated are as follows:

(a) Did individuals state where they were when this event occurred? 
(b) Was the feeling of living in the recollection overtly dominant in the narrative?

(c) Did individuals state what they were doing when this event occurred?

(d) Did individuals state who was with them when this event occurred? Can they remember the name of any of these people?

(e) Did the individual state the first thought that passed through his mind when this event occurred?

(f) Do they believe that the recollection occurred exactly as they recalled?

(g) Specificity/generality of the recollection (Was the recollection specific to the individual's life?).

(h) Emotional resistance (Did they feel the emotions while recalling as intensely as they did when the event really happened?).

(i) Did their narration have integrity?

Third step: Narrative analysis of the selected recollections. Narratives play a significant role in psychological research, especially in recent years, as they have the content that best describes the events, actions, and personal experiences (Feldman et al., 2004; Jovchelovitch \& Bauer, 2000). The main purpose in narrative analysis is to reveal the way the message is expressed and the underlying message of the text. Within this context, narrative analysis focuses on (a) structural analysis of the narrative (i.e., the discourse of the text or how the story is told) and (b) thematic analysis of the narrative (i.e., what is told in the story and what happened to whom). Narrative analysis provides thematic content based on the narrative as well as the linguistic aspect including mono-logical and textual analysis (Bamberg \& Cooper, 2012; Riessman, 2008).

In this study, structural analysis of the narrative was carried out using Labov's narrative method. In Labov's approach, a fictionalized form of the narrative is as follows, and this form was used in the structural analysis of this study (Labov \& Waletsky, 1967; Tanyaş, 2014): (a) Abstract: What is the narrative about? (b) Orientation: Who, when, where? (c) Complicating action: What happened? (d) Evaluation: What is the importance of this narrative? (e) Result: What happened in the end?

The main theme of a text is defined as "the principal idea that constitutes the basis of a text; the main idea," by the Turkish Language Association (Türk Dil Kurumu [TDK], n.d.) and is explored by questions like "What is the most comprehensive conclusion to infer from this paragraph? What is the point that is essentially trying to be emphasized?" Theme is defined as "the main subject; basic motif; main topic," 
by TDK (n.d.) and is typically determined by discovering the basic feeling or idea that the narration is trying to convey. The evaluation and result sections of Labov's narrative method can help one get an idea of this. Furthermore, as the purpose of this study is to question the relationship between the thematic meaning of one's early recollections and life styles, the narrative method for thematic analysis has also been used (Bamberg \& Cooper 2012; Feldman et al., 2004; Jovchelovitch \& Bauer, 2000). The most practical approach in thematic analysis is regarded as dividing the text into smaller parts (Jovchelovitch \& Bauer, 2000). For this purpose, first a summary is obtained that covers the whole text. Thereafter, this summary is commented on. The purpose of commenting is to paraphrase with the aim of achieving a more functional reduction. Then, this commentary is turned into a few keywords. So, the text is turned into three columns. The first column includes a summary of the transcription, the second column includes the first paraphrasing, and the third column includes only the keywords. Some thematic analyses contain more than one step (Feldman et al., 2004; Jovchelovitch \& Bauer, 2000). In this study, thematic commentary on the narrative was approached in the same manner, and the keywords achieved in this step were used to describe the similarities between early recollections and life style.

Fourth step: Comparison of the early recollection narratives and life style content obtained through the Adlerian interviews. In this part, similarities between the thematic emphasis put on the early recollection narratives and the emphasis put on the main themes of life styles obtained through the Adlerian interviews were described. This description took as its basis the compatibility of the particular action emphasized by the client in their recollection with the action-content emphasized in the life style as recommended by the literature. Similarly, the suggestion of the literature to pay attention to the action stated in the first sentence of the individual's narrative was also followed (Clark, 2001; Maree, 2013).

Fifth step: Comparison of the results and parent schemas. Establishing a correlation between the life style recollection themes as well as early recollections' main themes and perceived parenting styles was attempted. Results of each case were re-evaluated from the perspective of the parent schema. Perceived parenting styles of the participants were determined based on the results of their individual Young Parenting Inventory. This inventory includes questioning various behaviors of the individual's parents that are thought to constitute the basis of early maladaptive schemas in the individual and serves the purpose of the study in this regard. The inventory requires the assessment of the questions for both mother and father. Thus, it helps to gain separate results based on whether the mother or the father was mentioned in the early recollections. The obtained parent schemas were evaluated according to the main content of the schemas and compared with similar themes that can be attributed to the schemas. 


\section{Validity and Reliability of the Study}

Direct quotations have been included in order to improve the internal reliability of the study. Efforts were made to create an environment where participants could feel relaxed and able to sincerely express themselves, having enough time for their narratives. Attention was given to choosing the themes from among the main text and to covering the relevant concepts. The narratives of the volunteer group that were included in the analysis were chosen from the recollections that met the autobiographical memory qualifications; the ones that did not meet this list of criteria were excluded. This process improved the internal validity of the study. The study process was described in detail in order to improve its external validity. To this end, the research model, study group, data collection tool, and data analysis have been extensively described.

\section{Findings}

First of all, the results of the Adlerian interview carried out with the three participants who met the criteria of autobiographical memory qualifications were transcribed and summarized in the findings section. The whole interview was not included but instead presented as a summary in the interest of saving space. However, the main theme of the interview was identified (as recommended in narrative analyses) and then summarized, thus emphasizing the interesting points that provided clues about life style (Feldman et al., 2004). Structural analysis of the transcribed early recollection narratives was then performed by Labov's narrative analysis method. Afterwards, thematic analysis of the narrative took place, and then the similarities between early recollections' content and life style, as obtained through the Adlerian interview for each case, were discussed over themes. The results of each case were then re-evaluated from the aspect of parent schema. Case presentations did not include real names.

\section{Case Study 1}

Nickname: A. Male. He is 26 years old and the oldest son in the family. He has a brother two years younger than him. He had another sibling who died when he was a few months old. He works in his father's market and deals with trade.

Summary of the information obtained through the Adlerian interview. He mostly focused on telling about his relationship with his father. He gets along well with his mother and brother, in general. He is highly self-confident, talkative, presentable, and ambitious about earning money; he has strong communication skills and appreciates himself highly. He thinks that his father has the same characteristics and that he got these from him. His father deals in trade. He made a lot of money in the past but went bankrupt. Mentioning mostly his father during the interview, A. Male primarily emphasized that he has been working with his father since an early ages and mentions his markets when talking about his childhood. He stated that his father has been taking 
him to the workplace and even to meetings since an early age, and he has always been involved in the business. He said that he was highly affected by his father's bankruptcy and is afraid of not being able to reach his goals in life. He is also afraid of arguing with his father and making him angry. He feels a lot of responsibility on his shoulders as the older child in the family. He stated that he experiences sudden outbursts of anger from time to time and hits the table. He underlined that he is very self-confident. He frequently emphasized that he has received compliments from those in his environment about how he is very talented, communicative, ambitious, and so on. However, aside from his self-confidence, he is afraid of failing. He says, "I would rather do nothing than do something and fail." He thinks people are unreliable and frequently emphasized the sentence "one shouldn't trust even his father." One of his siblings died one month after A. Male was born. In his words, this caused him to fear losing his loved ones.

Interesting points that provided clues about the life style obtained through the Adlerian interview. (a) He thinks his personality is very similar to his father's. (b) The prominent base in his life is his father's workplace, and business life dominates his relationship with his father. (c) He is afraid of not being able to achieve his goals in life, of losing, of failing, of arguing with his father; and of making him angry. (d) He feels a lot of responsibility on his shoulders. (e) He is extremely self-confident. (f) He has sudden outbursts of anger. (g) He doesn't trust people.

\section{Analysis of A. Male's early recollections according to Labov's structural analysis model.}

Abstract. What is the narrative about? It is about a theft that happened in the market where he was working with his father at the age of six and about his father's reaction to this event.

Orientation. Who, when, where? A. Male estimates that he was around six years old in his recollection. The characters he seemed to recall in his recollection were himself, his father, and the theft committed by someone working in their market.

Complicating action. What happened then? His father realized that one of the workers in their market had stolen something. He reacts suddenly, catches the worker, and severely beats him in front of A. Male.

Evaluation. What is the importance of this narrative? A. Male knew and communicated with the person who was beaten and fired in front of him; they had worked together for a while. A. Male was very surprised that someone he knew had stolen something and had caused him to feel distrust.

Result. What happened in the end? He witnessed his father's sudden anger. He saw that someone he knew was actually a thief. 
Note about A. Male. After A. Male narrated this recollection, he wanted to emphasize another recollection which he recalled together with this one. He stated that he was younger in this recollection and that he had damaged goods in the market while misbehaving. Unexpectedly, his father was not angry with him, and this unexpected reaction from his father made him feel strong, confident, and capable of doing anything.

Thematic narrative analysis of the early recollections of A. Male.

Table 1

Thematic Narrative Analysis of the Early Recollections of A. Male

\begin{tabular}{lll}
\hline Abstract of the transcription: & Paraphrase & Keywords (themes) \\
\hline Someone that he knew and that worked in his & (a) Someone that he knows and that & His father's market \\
father's market stole something when he was & works in his father's market & Someone he knows. \\
6. When his father realized this unexpected & (b) unexpectedly steals something, & Unexpected event. \\
situation, he suddenly stood up and severely & (c) his father reacts suddenly once it & Sudden reaction \\
beat his worker in front of A. Male. A. Male & is realized & Case of beating \\
was affected by the fact that someone he knew & (d) his father beats this worker in front & Feeling of insecurity. \\
tried to rob them. He feels insecure. & of A. Male. & \\
\hline
\end{tabular}

Comparative analysis of the similarities between the early recollections of A. Male and his life style obtained through the Adlerian interview. (a) One of the interesting points from the Adlerian interview of A. Male was his emphasis on his father and his father's workplace. The narrative stated by A. Male as his early recollections included his father, and the recollection also took place in his father's workplace. This is compatible with the keyword of father's market obtained from the thematic analysis of his early recollections. (b) A. Male emphasized that he has sudden outbursts of anger. His early recollection when his father stood up with a sudden reaction and beat the worker is compatible with his first recollection. This is compatible with the keywords of unexpected event and sudden reaction also achieved by thematic analysis. (d) Another result gained from the Adlerian interview is that A. Male thinks people are unreliable. It is interesting that the early recollection of A is related with his trust being damaged by someone he knows; this person's stealing disappointed him. This is compatible with the feeling of distrust theme obtained by thematic analysis. (d) The emphasis on making his father angry, arguing with his father, and letting him down being among A's fears is remarkable in terms of its similarity with the content of his early recollections. The unpleasant ending that happened to someone who made his father angry and let him down in his early recollections constituted the main theme. This narrative is compatible with the themes of beating event and unexpected event obtained from the thematic analysis. (e) The statement of A. Male about "feeling strong, confident, and capable of doing anything" regarding the second recollection he remembered during the association of his early recollections is compatible with the definitions about his personality obtained from the Adlerian interview. 
Evaluation of parent schema of A. Male. According to the results from the Young Parenting Inventory, the perceived parenting style of A. Male regarding his father was defined as conditional/achievement-focused parenting. The items checked by A. Male included "he always expected me to do the best," "he gave importance to social status and appearance," "he was extremely concerned about what situation my behaviors would put him in the eyes of others," "he loved me more or he was more attentive to me when I was successful," and so forth. This result appears compatible with A. Male's fears about not being able to achieve his goals in life, failing, arguing with his father, making him angry, and the feeling of responsibility on his shoulders. Additionally, the emphasis A. Male put on the feedback he had received from the outer world about his being very successful and talented during the interview may suggest that he created a belief that he should be successful to gain love, which is directly proportional to his perceived parenting approach. The result of his early recollections about people being unreliable also suggests his perception of his father's parenting as conditional. It has been concluded that A. Male's perception of his mother's parenting, which he didn't mention much during the interview, was emotionally satisfactory.

Result. A Male's life style, based on his sentence, “one shouldn't trust even his father," as emphasized in the Adlerian interview; the thematic stress of distrust in people regarding his early recollections; and his perceived conditional/achievementfocused parenting style are compatible with and explain each other.

\section{Case Study 2}

Nickname: B. Female. She is 23 years old and single. She is a student and has two older sisters and one younger brother.

Summary of the information obtained through the Adlerian interview. Most of B. Female's words focused on her poor relations with her mother and grandmother. B. Female can express herself very well, is well-groomed, speaks quickly and nonstop; she is lively and short-tempered. She doesn't like making eye contact. She turns her eyes away. She uses her hands a lot when she speaks. She stated that she often has stomachaches and sometimes headaches. She is tense in general. She said that she had never gotten along with her grandmother since her childhood, and now they are at odds. She does not get along with her mother, either; she said that there has always been a distance between them. Her grandmother left her mother when her mother was three. They were only able to find her grandmother after her mother had gotten married. B. Female grew up listening to her mother's complaints and even to her weeping about being abandoned. She thinks that her grandmother doesn't love her or her mother much. She also believes that the grandmother discriminates between her mother and her mother's brothers, and that she treats her mother unfairly. She defined her relation with her mother as normal, even as sincere, but stated that she cannot get 
along with her mother. She doesn't see her siblings very often. She has been living apart from her family for a long time and now stays in a dorm. She thinks her mother doesn't miss her much. She had had times when she was estranged for a long time from her mother and grandmother. She stated a few times that she felt "abandoned" in general. She said that "she feels as if she was the mother" when she defined her relationship with her mother. She says that she is good at social relations but finds women and girlfriends to be unreliable, sinister, and sneaky. She thinks that she can make friends with men better and that they are more trustworthy. She believes that, in her own words, women can cheat any time. She emphasized that she has more boyfriends than girlfriends because of this. She holds that men say whatever they think, but women can never be trusted.

Interesting points that provided clues about the life style obtained through the Adlerian interview. (a) Her focus is mostly on her mother and grandmother and her relations with them. (b) Her relations with the women in her life are poor. (c) She grew up listening to the story of her mother being abandoned by her grandmother. (d) She finds women and girlfriends unreliable, sinister, and sneaky. (e) She feels abandoned. (f) She has an estranged relationship with her mother and feels as if she was the mother.

\section{Analysis of B. Female's early recollections according to Labov's structural analysis model.}

Abstract. What is the narrative about? Her early recollection is about her mother being hospitalized for a long-term treatment due to a sudden and serious disorder.

Orientation. Who, when, where? She was 4 years old and her brother had just been born. She recalled that her brother was still breastfeeding.

Complicating action. What happened then? Her mother stayed in the hospital for a long time and her father stayed with her mother. Her older sisters, her brother, and she were very young and were left alone. In the end, their aunt had to take care of them. She even remembered that her aunt had breastfed her brother.

Evaluation. What is the importance of this narrative? She felt abandoned and all alone during that period. She remembers very well how lonely and bad she felt without her mother and father.

Result. What happened in the end? Her mother and father returned home in the end, but she said she is still afraid that her loved ones will suddenly leave her. Yet, she also says that she would never tell people that she fears losing them because they can use this against her and break her heart. 
Analysis of B. Female's early recollections through thematic narrative analysis.

Table 2

Thematic Narrative Analysis of the Early Recollections of B. Female

\begin{tabular}{lll}
\hline Abstract of the transcription: & Paraphrase & Keywords (themes) \\
\hline Her mother had a serious disorder and & $($ a $)$ Her mother got sick suddenly & Sudden disorder \\
stayed in hospital when she was 4. When & (b) her father left home to take care of & Being left alone \\
her father left home to take care of her her mother & Feeling abandoned \\
mother, she and her siblings were left alone. & (c) she and her siblings were left alone & Feeling left alone \\
She felt abandoned and all alone. She start- & $(d)$ she felt abandoned and all alone & Fear of being aban- \\
ed to fear that her loved ones would leave & $($ e) she's afraid that her loved ones will doned & \\
her. She thinks that her loved ones can leave her & Her loved ones break \\
break her heart, so she doesn't want to tell & (f) she can't tell them about this due to her heart \\
them about her fear. & her fear that they would break her heart &
\end{tabular}

Comparative analysis of the similarities between the early recollections of $B$. Female and her life style obtained through the Adlerian interview. (a) B. Female emphasized her mother and grandmother, and she focused on her relations with them through most of her interview. Her early recollection was about an event related with her mother. (b) She grew up with the information that her mother had been abandoned by her grandmother. Her early recollection also related to feeling abandoned. This is compatible with the keywords of being left alone and feeling abandoned obtained from the thematic analysis of her early recollections. (c) During the life style interview, the theme was being abandoned regarding her mother and grandmother, and she was found to not trust women or girlfriends. The fact that women were often mentioned in the themes of her experiences of being left alone and abandoned appears similar to her mood about finding her girlfriends and women unreliable. This is compatible with the themes of being left alone, being abandoned, and her loved ones breaking her heart in her early recollections. (d) The emphasis on feeling alone, as stated by B. Female during the Adlerian interview, is compatible with the keywords of sudden disorder, being left alone, and being abandoned, as obtained from the thematic analysis.

Evaluation of parent schema of B. Female. According to the results of the Young Parenting Inventory, while B. Female's perceived parenting style of her father was emotionally satisfactory, it was also determined to comply with the overprotective/ anxious parenting style. Her perceived parenting of her mother was determined to center on the restricted/emotionally inhibited and normative parenting styles. The items checked by B. Female in the restricted/emotionally inhibited parenting style included "she was uncomfortable with expressing her feelings, she was introverted" and "she rarely revealed her feelings." Her choices and the normative parenting style of her mother are compatible with her emphasis on the estranged relationship she has with her mother.

Result. The themes of feeling alone and distrusting women were generally emphasized by B. Female; the keywords of feeling abandoned, feeling left alone, 
and her loved ones breaking her heart, as obtained from the thematic analysis, are compatible with each other. These keywords are compatible with her current schemas about her mother, which was the focus of her narrative, as well as the result that she doesn't feel close to her mother.

\section{Case Study 3}

Nickname C. Female. She is a 21 -year-old university student and has a twin sister.

Summary of the information obtained through the Adlerian interview. She is extremely warm and friendly. She defined herself as being happy, cheerful, and in love with traveling. She is a successful student. She likes her department. She has good family relations. She said her family is very close to each other and she is devoted to her family. She gets along with her twin very well. Although they are twins, her sister is more like their older sister. She stated that she always felt the love of her mother and father when she was a child. She thinks that her family and her twin sister are close, full of love, and supportive. She said, "I have always felt peaceful spending time with them since my childhood."

Interesting points that provided clues about the life style obtained through the Adlerian interview. (a) She defined her family as peaceful. (b) She defined herself as happy, cheerful, and a travel lover. (c) She likes spending time with her family.

\section{Analysis of C. Female's early recollections according to Labov's structural analysis model.}

Abstract. What is the narrative about? It is about the day she had a lot of fun with her father and twin sister.

Orientation. Who, when, where? She was 4 years old in her early recollections. She was with her twin sister and her father and they were going to the cinema. They were outdoors on a rainy and muddy day.

Complicating action. What happened then? It rained a lot and pools of mud were collected on the streets. Potholes in the pavement were filled with water. C. Female liked jumping in and out of the water-filled potholes, but her mother didn't allow it lest she get sick. C. Female couldn't help but jump in the pothole. Her sister followed her. It was so deep that they got soaked and covered with mud. They were worried that their father would get angry and tell their mother, but their father jumped in the pothole and started bouncing.

Evaluation. What is the importance of this narrative? The client said she'd had a lot of fun and she has never forgotten that moment. 
Result. What happened in the end? C. Female thinks that she always feels happy and peaceful when she is with her family.

Analysis of C. Female's early recollections through thematic narrative analysis.

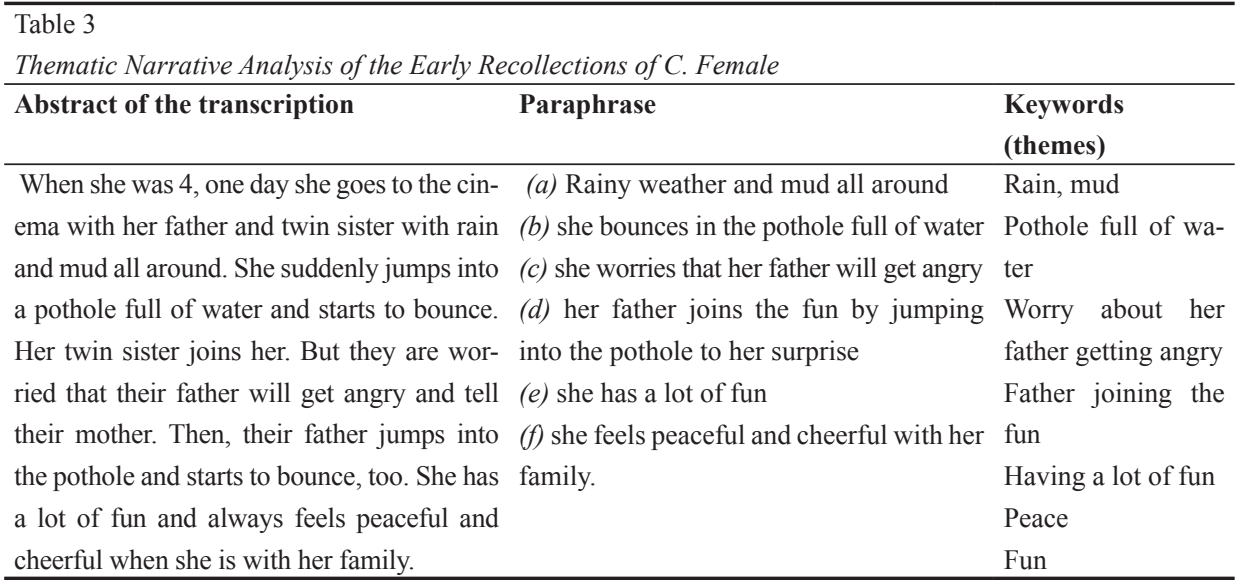

Comparative analysis of the similarities between the early recollections of $\mathbf{C}$. Female and her life style obtained through Adlerian interview. (a) C. Female's definition of herself as a happy and cheerful person during the Adlerian interview is compatible with the keywords of having a lot of fun and fun obtained from the thematic analysis. (b) Both during the Adlerian interview and in her early recollections, $\mathrm{C}$. Female mentioned the peace she feels when she's with her family.

Evaluation of C. Female's parent schema. It was concluded that C. Female has common schemas for both her mother and father. C. Female's twin sister was also asked to fill in the Young Parenting Inventory, and she was seen to provide the same schemas. The perceived schemas of both parents showed that they were not emotionally depriving parents. Both twins also evaluated their parents in the category of overprotective/anxious. A parent that is not emotionally depriving is a reversescored factor in the inventory. High scores in this section show that the family is not emotionally depriving. Remarkable choices of both sisters related to this factor included definitions like "she/he loved me and treated me like I am special", "she/he was warm to me and physically affectionate." These definitions were in proportion to C. Female's feeling peaceful with her family.

Result. C. Female's life style based on the concepts of peace, fun, and happiness, as emphasized during the Adlerian interview; the thematic emphasis of her narrative regarding her early recollections on father's joining the fun, peace, fun, and having a lot of fun; and her parents' perceived parenting style of emotionally not depriving all confirm each other. 


\section{Discussion}

Adler stressed that human behavior is developed within a social context, and therefore, therapy should take into consideration that context (Jones-Smith, 2014). In Yargic1's (2012) study, he questioned the contextual framework of personal experience narratives and proved that these narratives were not stable texts which transfer an experience as it was. Narrators make strategic choices with regard to what and how to narrate, as well as why to narrate in that manner, when organizing individual experiences and verbally narrating them. The narrative, which is a result of the narrating action and event as a whole, is the result and product of the choices of the narrator made according to the narrative context. Therefore, the selected and narrated experiences are so holistic that it cannot be called coincidence. Clients A. Male and B. Female were seen to have negatively perceived parent schemas in response to their narratives with their negative life style and early recollection themes. C. Female, on the contrary, had positive early recollection and life style themes in response to her positive perceptions with regard to her mother and father. Hinnen, Sanderman, and Sprangers (2009) studied adult attachment from the viewpoint of the instrumental role of satisfaction in life and childhood recollections. As a result of the tests that analyzed the childhood recollections provided by 437 participants, they found that recollections of a warm and harmonious family atmosphere were associated with secure attachment, and negative childhood recollections, such as abuse or pathological parents, were associated with insecure attachment. Additionally, adults who develop secure attachment seem to have more satisfactory perceptions about life.

Similarly, Barrett (1980) performed a study on 50 university students, which demonstrated that early recollections were indicators of personality tendencies. Barrett concluded that early recollections were especially associated with anxiety and focus of control. McFarland-Piazza, Hazen, Jacobvitz, and Boyd-Soisson (2012) studied the quality of care 117 fathers provided for their 8-month-old, newborn babies. Results showed that the childhood recollections and experiences of fathers themselves had a direct impact on the care they provided to their babies. Fathers who had recollections of parents putting pressure on them about success during their childhood showed more hostility and less sensitivity. Furthermore, fathers who experienced being neglected by their mothers during childhood treated their babies with extreme sensitivity and showed great care. Thus, early childhood experiences and relevant recollections were seen to lead to lifelong impacts on individuals, and these results confirm this study's findings.

Within this scope, dealing with the life style that has been established based on perceptions like early recollections, family life, and birth order in a therapeutic setting, as well as creating treatment schedules formed on the power of this connection, can create rapid and influential change. To this end, the study of Akdoğan and Ceyhan 
(2014) helped to create a group psychological counseling program with the purpose of earning skills for coping with feelings of inadequacy in university students within the framework of the Adlerian approach. Group sessions included activities about the source of these feelings of inadequacy. For this purpose, the factors that led up to the development of this feeling of inadequacy, such as early childhood experiences and early recollections, were addressed. The study focused on life style themes that were considered to be a result of factors such as family, sibling relations, and early recollections. Under the light of the insight gained by the clients with the Adlerian approach, the goal of the study became to help clients choose a more functional life style (over their previous mistaken life styles before their counseling) and to display the behavioral patterns required by this new life style. The selected method showed that group study was effective in relieving students' feelings of inadequacy.

When A. Male, B. Female, and C. Female were asked about their early recollections, they were respectively 6-, 4-, and 4-years old in their recollections. In Bauer, Tasdemir-Ozdes, and Larkina's (2014) study regarding the early recollection features of adults, they came to the conclusion that early recollections belonged mostly to the age of 4; another result showed that these recollections were highly permanent. Wells, Morrison, and Conway (2014) asked participants in their study about two of their early recollections of experiences: one positive and one negative. Based on the results, the average age was concluded to be 6 , and the most prominent details were related to activity, location, and people. These results are similar to the results of this study. Early recollections from all three participants were seen to be associated with their parents. Studies have shown that early recollections of adults are usually related with parent-child relations (Peterson, Smorti, \& Tani, 2008).

No study in Turkey has tested the relation between early recollections and life style, or the relation between early recollections and life style experiences with perceived parent schema. On the other hand, in the study of Soygüt and Çakır (2009), one of the rare studies examining the relations between parenting styles and psychological symptoms, the mediation of interpersonal schemas was explored. In their study, the interpersonal schemas of the individuals who had perceived their fathers as being conditional/achievement-focused were concluded to not be complete in terms of their dominance, while their passivity aspect was complete. That is, when these individuals take on the role of guiding or deciding in their relations with their father, they expect this role to be accepted by their fathers. On the other hand, when these individuals want their fathers to take over control in their relations in terms of passivity, they expect their fathers to approach them in accordance with their demand. The dominant schema of A. Male regarding his father in the parent schema evaluation was concluded to be conditional/achievement-focused parenting. What Soygüt and Çakır (2009) emphasized in the results of their study is similar to the dominant 
themes found in the early recollections of A. Male, as well as the connection to his life style. Similarly in that same study, the perceived normative parenting style of the mother was shown to have a mediating role in the completion of the hostility aspect of interpersonal schemas. In other words, if an individual who thinks that they have been exposed to that parenting style develops an interpersonal schema pattern in which they believe that their mother would approach them in a distanced, cold, indifferent manner when they approach her in a cold, distant, indifferent manner, then they are more likely to display psychological symptoms in the future. This is similar to the relation between B. Female's estranged attitude towards her mother and her hostility towards her grandmother in her dominant narrative and her normative parent schema. Similarly, in the study of Şahin and Özer (2012) regarding the maternal form of Young Parenting Inventory, adolescents who think that they have a normative mother, as was the case with client B. Female, were concluded to be more likely to assess themselves and their relations in a negative manner.

In Şahin and Özer's (2012) study, they explored the psychometric features of the maternal form of the Young Parenting Inventory on a group of adolescents. One of the conclusions of the study was the very significant and positive correlation found between the perception of an affectionate/loving mother and a positive selfassessment regarding self, future, and relations. In the current study, the positive themes of happiness and cheerfulness, which C. Female used to define herself, and her perceived positive parenting were also correlated. Within this scope, the early recollections and life style of C. Female were seen to have similar themes.

In the study of Soygüt et al. (2008), they drew attention to the possibility of the overprotective/anxious parenting style being perceived as functional in Turkey's collectivist-based culture. The fact that client $\mathrm{C}$. Female and her twin sister received high scores in the perceived parenting styles of their mother and father in the aspect of overprotective/anxious parenting suggests that it might have been perceived as functional for the same reason when assessed within the holistic framework of their life styles and early recollection experiences. This conclusion suggests that judging by the life style and early recollection experiences of individuals (by taking a holistic approach) is important when assessing individuals' parent schemas.

Schema actions are open to change throughout life, or an individual may use more than one schema (Young \& Klosko, 2013). As the impact on an individual of the connection between early recollections and life style can be confirmed, this information can provide the interactions in counseling with an important clue. Therefore, if the value individuals attribute to their life through their early recollections and life style experiences inhibit them and block development, it may be possible to help them gain awareness through narratives and impact their schema actions within this context. 
This study attempts to shed light on future studies that may be designed towards this purpose. Future studies may include exploring the relationship of Adlerian concepts, such as early recollections, life style, and birth order, with various concepts to test their effectiveness. To this end, the study of Akdoğan and Ceyhan (2014), in which they created a group psychological counseling program for the purpose of gaining skills to cope with the feeling of inadequacy in university students within the framework of the Adlerian Approach, can be shown as an example.

While studies that emphasize early recollections as a likely indicator of personality tendencies (Barrett, 1980; Rule, 1992) have been conducted for many years in the literature outside of Turkey, no such studies exist in Turkey. For instance, Rule (1992) examined 500 studies to address the relationship of early recollections (as emphasized by Adler) with personality problems, demonstrating the relationship of early recollections with current life style and its potential use in therapy as a diagnostic and facilitating element. Studies to be carried out with this purpose in Turkey may have a valuable guiding role in terms of showing how the Adlerian method can be used in a therapeutic setting.

Furthermore, a quantitative evaluation of the relationship with parent schemas, as emphasized in this study, can be carried out on more extensive sampling groups when various inventories (Crandall, 1991; Wheeler, Kern, \& Curlette, 1986) that test Adlerian therapy contents, such as life style, are adapted into Turkish.

It was not possible to generalize the results due to the concern of being speculative, because the study had been conducted on a limited sampling group due to its structure. However, we hope that it will open the door for similar studies that can be supplemented with quantitative data through more comprehensive and extensive sampling groups.

\section{References}

Akdoğan, R., \& Ceyhan, E. (2014). Adleryen grupla psikolojik danışmanın yetersizlik duygusu ve psikolojik belirtiler üzerindeki etkisi [The effect of Adlerian group counseling on feelings of inadequacy and psychological symptoms]. Türk Psikolojik Danışma ve Rehberlik Dergisi, 5(42), 280-293.

Arntz, A., \& van Genderen, H. (2013). Sinır kişilik bozukluğu için Şema Terapi [Schema therapy for borderline personality disorder]. Istanbul, Turkey: Psikonet Yayınları.

Bamberg, M., \& Cooper, I. H. (2012). Narrative analysis. In H. Cooper (Ed.) APA handbook of research methods in psychology (Vol. 2, pp. 77-94). Washington, DC: APA Press.

Barrett, D. (1980). The first memory as a predictor of personality traits. Journal of Individual Psychology, 36(2), 136-49.

Bauer, P. J., Tasdemir-Ozdes, A., \& Larkina, M. (2014). Adults' reports of their earliest memories: Consistency in events, ages, and narrative characteristics over time. Consciousness and Cognition, 27, 76-88. http://dx.doi.org/10.1016/j.concog.2014.04.008

Bienenfeld, D. (2005). Psychotherapy in clinical practice: Psychodynamic theory for clinicians. Philadelphia, PA: LWW. 
Bricker, C. D., \& Young, J. E. (2012). A client's guide to schema therapy. New York, NY: Schema Therapy Institute, Cognitive Therapy Center of New York.

Clark, A. J. (2001). Early recollections: A humanistic assessment in counseling. The Journal of Humanistic Counseling, Education and Development, 40(1), 96-104.

Crandall, J. E. (1991). A scale for social interest: Individual psychology. Journal of Adlerian Theory, Research \& Practice, 47(1), 106-114.

Eisenberger, N. I. (2011). Why rejection hurts: What social neuroscience has revealed about the brain's response to social rejection. Brain, 3(2), 1.

Er, N., \& Uçar, F. (2004). Yoğun duygu yüklü yaşam olaylarında kişisel anı aktarımları ve referans noktaları aracılığıyla otobiyografik bellek örüntülerinin incelenmesi [Patterns of autobiographical memory through transfer of personalized memory and reference points in intense emotional life events]. Türk Psikoloji Dergisi, 19(53), 1-18.

Feldman, M. S., Sköldberg, K., Brown, R. N., \& Horner, D. (2004). Making sense of stories: A rhetorical approach to narrative analysis. Journal of Public Administration Research and Theory, 14(2), 147-170. http://dx.doi.org/10.1093/jopart/muh010

Gilbert, P., Cheung, M., Grandfield, T., Campey, F., \& Irons, C. (2003). Recall of threat and submissiveness in childhood: Development of a new scale and its relationship with depression, social comparison and shame. Clinical Psychology \& Psychotherapy, 10(2), 108-115.

Hinnen, C., Sanderman, R., \& Sprangers, M. A. (2009). Adult attachment as mediator between recollections of childhood and satisfaction with life. Clinical Psychology \& Psychotherapy, 16(1), 10-21. http://dx.doi.org/10.1002/cpp.600

Jones-Smith, E. (2014). Theories of counseling and psychotherapy: An integrative approach. Thousand Oaks, Ca: Sage. Retrieved from http://www.sagepub.com/upm-data/40298 Smith_(TCP)_03_watermarked.pdf

Jovchelovitch, S., \& Bauer, M. W. (2000). Narrative interviewing. In M. W. Bauer \& G. Gaskell (Eds.), Qualitative researching with text, image and sound: A practical handbook (pp. 57-74). Thousand Oaks, CA: Sage.

Kaplan, H. B. (1985). A method for the interpretation of early recollections and dreams. Individual Psychology-The Journal of Adlerian Theory Research \& Practice, 41(4), 525-532.

Labov, W., \& J. Waletsky. (1967). Narrative analysis. In J. Helm (Ed.), Essays on the verbal and visual arts (pp. 12-44) Seattle, WA: University of Washington Press.

Maree, J. G. (2013) Counseling for career construction: Connecting life themes to construct life portraits: Turning pain into hope. Rotterdam, Netherlands: Sense Publishers.

Matos, M., Gouveia, J. P., \& Duarte, C. (2015). Constructing a self protected against shame: The importance of warmth and safeness memories and feelings on the association between shame memories and depression. International Journal of Psychology and Psychological Therapy, 15(3), 317-335.

McFarland-Piazza, L., Hazen, N., Jacobvitz, D., \& Boyd-Soisson, E. (2012). The development of father-child attachment: Associations between adult attachment representations, recollections of childhood experiences and caregiving. Early Child Development and Care, 182(6), 701-721. http://dx.doi.org/10.1080/03004430.2011.573071

Mosak, H. H., \& Maniacci, M. (2012). Adlerci Psikoterapi [Adlerian psychotherapy]. In R. J. Corsini \& D. Weddings (Eds.), Modern psikoterapiler (pp. 115-178). Istanbul, Turkey: Kaknüs Yayınları.

Murdock, N. L. (2012). Psikolojik danışma ve psikoterapi kuramları [Theories of counseling and psychotherapy] (F. Akkoyun, Trans.). Ankara, Turkey: Nobel Yayınevi.

Panksepp, J. (1998). Affective neuroscience. New York, NY: Oxford University Press. 
Perry, B. D. (2002). Childhood experience and the expression of genetic potential: What childhood neglect tells us about nature and nurture. Brain and Mind, 3(1), 79-100.

Peterson, C., Smorti, A., \& Tani, F. (2008). Parental influences on earliest memories. Memory, 16(6), 569-578. http://dx.doi.org/10.1080/02687030802025984

Polkinghorne, D. E. (2000). Narrative therapy. In A. E. Kazdin (Ed.), Encyclopedia of psychology (pp. 387-389). Washington, DC: American Psychological Association.

Prochaska, J. O., \& Norcross, J. C. (2010) Systems of psychotherapy (7th ed.). Belmont, CA: Brooks/Cole.

Richter, A., Gilbert, P., \& McEwan, K. (2009). Development of an early memories of warmth and safeness scale and its relationship to psychopathology. Psychology and Psychotherapy: Theory, Research and Practice, 82(2), 171-184.

Riessman, C. K. (2008). Narrative methods for the human sciences. Thousand Oaks, CA: Sage.

Rule, W. R. (1992). Associations between personal problems and therapeutic intervention, early recollections and gender: Individual psychology. Journal of Adlerian Theory, Research \& Practice, 48(1), 119-128.

Sarp, N., \& Tosun, A. (2011). Duygu ve otobiyografik bellek [Emotion and autobiographical memory]. Psikiyatride Güncel Yaklaşımlar-Current Approaches in Psychiatry, 3(3), 446- 465.

Sommers-Flanagan, J., \& Sommers-Flanagan, R. (2004). Counseling and psychotherapy theories in context and practice. Hoboken, NJ: Wiley \& Sons.

Soygüt, G., \& Çakır, Z. (2009). Ebeveynlik biçimleri ile psikolojik belirtiler arasındaki ilişkilerde kişilerarası şemaların aracı rolü: Şema odaklı bir bakış [The mediating role of schemas in the relation between parenting styles and psychological symptoms: A focused view of schema]. Türk Psikiyatri Dergisi, 20(2), 144-152.

Soygüt, G., Çakır, Z., \& Karaosmanoğlu, A. (2008). Ebeveynlik biçimlerinin değerlendirilmesi: Young Ebeveynlik Ölçeğinin psikometrik özelliklerine ilişkin bir değerlendirme [Evaluating parenting styles: Psychometric properties of the Young Parenting Inventory]. Türk Psikoloji Yazılarl, 11(22), 17-30.

Şahin, N. H., \& Özer, M. (2012). Young Ebeveynlik Ölçeği-Anne Formu (YEBÖ-A) Psikometrik Özelliklerinin Bir Grup Ergen Üzerinde Değerlendirilmesi [Evaluating the Young Parenting Inventory- Maternal Form on the psychometric properties of an adolescent group]. Türk Psikoloji Yazllarl, 15 (30), 37-49.

Talarico, J. M., LaBar, K. S., \& Rubin, D. C. (2004). Emotional intensity predicts autobiographical memory experience. Memory \& Cognition, 32(7), 1118-1132.

Tanyaş, B. (2014). Nitel araştırma yöntemlerine giriş: genel ilkeler ve psikolojideki uygulamalar1 [Introduction to qualitative research methods: General principles and applications in psychology]. Eleştirel Psikoloji Bülteni, 5, 25-38.

Türk Dil Kurumu. (n.d.). Güncel Türkçe sözlük [Daily Turkish dictionary]. Retrieved from http://www.tdk.gov.tr

Ulutürk, U. 2014. Şema terapi [Schema therapy]. In A. N. Canel, (Ed.), Terapide yeni ufuklar (Vol. 2, pp. 57-88). İstanbul, Turkey: Pinhan.

Ünal, B. (2012). Early maladaptive schemas and well-being: Importance of parenting styles and other psychological resources (Doctoral dissertation, Middle East Technical University, Ankara, Turkey). Retrieved from https://tez.yok.gov.tr/UlusalTezMerkezi/

Wells, C., Morrison, C. M., \& Conway, M.A. (2014) Adult recollections of childhood memories: What details can be recalled? The Quarterly Journal of Experimental Psychology, 67(7), 1249-1261. http://dx.doi.org/10.1080/17470218.2013.856451

Wheeler, M. S., Kern, R. M., \& Curlette, W. L. (1986). Factor analytic scales designed to 
measure Adlerian life style themes. Individual Psychology, 42(1), 1-17.

Yapıcı, Z. K. (2012). Kişisel deneyim anlatılarının bağlamsal çerçevesi: deneyimlenen, hatırlanan ve anlatilan hayat [Conceptual framework of the personal experience narrative: Life lived, remembered, and described]. Milli Folklor, 24(93), 207-219.

Yıldırım, A., \& Şimşek, H. (2003). Sosyal bilimlerde nitel araştırma yöntemleri[Qualitative research methods in the social sciences]. Ankara, Turkey: Seçkin Yayınları.

Young, J. E., \& Klosko, J. S. (2013). Hayatı Yeniden Keşfedin. Bilişsel ve Davranışçı Terapiler Serisi - 5 [Rediscovering life: Cognitive and behavioral therapies series -5] (3rd ed.). Istanbul, Turkey: Psikonet Yayınları.

Young, J. E., Klosko, J. S., \& Weishaar, M. E. (2003). Schema therapy: A practitioner's guide. New York, NY: Guilford Press.

\section{Appendix}

Adlerian Interview Questions (Jones-Smith, 2014, pp 15-16)

What are your complaints?

What was your situation when you first noticed your symptoms?

What is your situation now?

What is your occupation?

Describe your parents as to their character and their health. If not alive, what illness caused their death? What was their relation to you?

How many brothers and sisters do you have? What is your position in birth order? What is their attitude toward you? How do they get along in life? Do they have any illness?

Who was your father's or your mother's favorite child? What kind of up-bringing did you have?

Inquire for signs of pampering in childhood (timidity, shyness, difficulties in forming friendships, disorderliness).

What illnesses did you have in childhood and what was your attitude to them?

What are your early childhood recollections?

What do you fear, or what did you fear the most?

What is your attitude toward the opposite sex? What was it in childhood and later years?

What occupation would have interested you the most? If you did not adopt it, why not?

Is the client ambitious, sensitive, prone to outbursts of temper, pedantic, domineering, shy, or impatient?

What sort of people are around you these days? Are they impatient, bad-tempered, or affectionate?

How do you sleep?

What dreams do you have? (Of falling, flying, recurrent dreams, prophetic, about examinations, missing a train?)

What illnesses are there in your family background? 